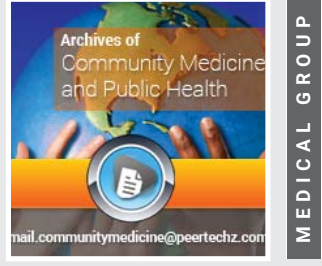

\section{Technology transfer model for the formulation stage in biological products for public health}

\section{Jorge L Magalhães ${ }^{1,2 *}$, Alessandra L Viçosa ${ }^{3}$, Giselle Ribeiro de Barros ${ }^{4}$}

${ }^{1}$ Technological Innovation Center and Professional Postgraduate Program in Management, Research and Development in the Pharmaceutical Industry, Institute of Drug Technology, Oswaldo Cruz

Foundation, Rio de Janeiro, RJ, Brazil

${ }^{2}$ Global Health and Tropical Medicine, GHTM, Instituto de Higiene e Medicina Tropical, IHMT,

Universidade Nova de Lisboa, UNL, Lisboa, Portugal.

${ }^{3}$ Department of Galenic Innovation, Deputy Direction of Education, Research and Innovation, Institute of Drug Technology, Oswaldo Cruz Foundation, Rio de Janeiro, RJ, Brazil

${ }^{4}$ Final Processing Department, Biomanguinhos, Oswaldo Cruz Foundation, Rio de Janeiro, RJ, Brazil
Received: 04 May, 2020

Accepted: 25 May, 2020

Published: 26 May, 2020

*Corresponding author: Jorge L Magalhães,

Technological Innovation Center and Professional Postgraduate Program in Management, Research and Development in the Pharmaceutical Industry, Institute of Drug Technology, Oswaldo Cruz Foundation, Rio de Janeiro, RJ, Brazil, E-mail: jorge.magalhaes@far.fiocruz.br

Keywords: Public Health; Technology transfer model; Public private partnership; Medicines

https://www.peertechz.com

Check for updates

\begin{abstract}
Technology transfer is a tool used to absorb knowledge and technology, in addition to increasing a country's technological innovation. In the health sector, it is no different, especially in times of outbreaks, epidemics and global pandemic. Therefore, tools that assist in the creation of public policies contribute to the research, development and innovation of new technologies to produce vaccines and medicines. Thus, it proposes a universal technology transfer model based on International guides from the World Health Organization, Parenteral Drugs Association and the International Society of Pharmaceutical Engineering. It was concluded that the model ensures reliability between the parties and promotes a dynamic and rapid methodology for application in public health in the country.
\end{abstract}

\section{Introduction}

The pharmaceutical industry generates approximately US $\$ 1.3$ trillion in drug production. It invests hard in research and development, innovation, marketing and distribution of medicines, which run through serums, vaccines and medicines in order to treat public health problems [1]. In this process, several technologies are used and, in order to accelerate business and innovations, pharmaceutical companies use technology transfer (TT) as a process to strengthen the development of new drugs $[2,3]$. TT is defined as "a logical procedure that controls the transfer of any product along with its documentation and professional expertise between development and manufacturing or between manufacturing sites" [4]. According to Mohite and Sangle [3], it has two sources of financing: the public sector (including universities) and the private sector [3]. Immunobiologicals have a great impact on prophylaxis and reduced mortality in diseases caused by infection, especially for the needy population who do not have access to health services. Thus, TT is one of the strategies for a country to have access to technology to produce these drugs more quickly to serve the population $[4,5]$. In this way, this work allowed us to propose a model in order to subsidize evenly a TT methodology for the formulation of production processes. 


\section{Methods}

The World Health Organization (WHO), Parenteral Drugs Association (PDA) and the International Society of Pharmaceutical Engineering (ISPE) manuals were compared; WHO and PDA being selected. Experts (decision makers and technicians) from a Brazilian pharmaceutical company were unified and, in parallel, heard (authorization by the Brazilian Research Ethics Committee, opinion number 3,272,783).

\section{Results and Discussions}

According to WHO (2011) $80 \%$ of the world population does not have access to essential medicines. In this way, TT can become an excellent tool for pharmaceutical companies in developing or less developed countries, for example [6,7].

In the pharmaceutical industry, TT is used in processes such as the discovery and development of new drugs, from the beginning of the product's life cycle to large-scale commercialization. In addition, some of its objectives are to transfer the product within and between companies and the knowledge of the process, used as a basis for manufacturing, analytical tests, process validation and continuous improvement $[3,8]$. It is worth mentioning that TT serves to assist in the transition of the medicine from the research and development stage to the marketing stage, identifying the important information during this process and clarifying doubts in the TT of products for different manufacturing locations [3].

According to WHO [4], TT is a procedure that must follow pre-determined steps in order to transfer knowledge and previously acquired experience so that it can be developed or marketed by another company [4]. Technologies are transferred through different forms such as licensing, franchising, turnkey, joint ventures, subcontracting, scientific cooperation, among others [9]. The technology transfer project (PTT) in the pharmaceutical industry consists of planned and controlled actions based on well-defined acceptance criteria. They must be used in the manufacturing process, analytical method, packaging component or any other step or process throughout the life cycle of the drug from a place of origin [10]. The management of a TT requires the creation of a multidisciplinary team that must be supervised so that the execution of the transfer activities and the routine activities are accomplished without any type of damage occurring in both. Another important point to be considered is the interaction between the teams of the two companies, which must overcome problems such as language and time zone [10]. According to [11], understanding workflows in companies is a pressing need and process modeling is the best option for this understanding allowing companies to improve their processes, be more efficient, flexible, present competitive advantages and improve their services for customers and society [11-13].

Table 1 shows a summary of the recommendations expressed in each studied guide. Subsequently, to interviews with experts, it was possible to harmonize the results and propose a practical model for TT.

\section{Final considerations}

- Thus, after compiling the result of the interviews and standardized in the light of the comparison of the TT guides, the 4-phase model is proposed: Planning phase, preparation phase, qualification and validation phase and verification phase:Planning phase: SC and the RC must prepare a technology transfer plan that will guide the entire project and define the strategic approach with quality and risk management aspects. Define level and detail of the shared information. Verify that the facilities and equipment of the two units operate according to similar operating principles. The team must be quality assurance, quality control, production, regulatory affairs, engineering, finance, environmental management, health and safety, research and development and issues legal entities.

- Preparation phase: SC documentation is received and analyzed to carry out the process in the RC. Here the whole team is trained. Fortnightly followup meetings are established for the two companies. Minimum documentation: Product CQA, impurity profile, specifications (at least for APIcomponents / products and packaging), critical and non-critical process parameters, along with acceptable and proven ranges and ranges, manufacturing instructions, activity procedures related to the process, raw materials and auxiliaries, cleaning procedures, stability data available, validation documents (at least aseptic process and pathogen purification validation reports), process development documents (e.g. main technical reports and historical reports of the development process), previous regulatory record, manufacturing flow and process instructions, analytical methods and procedures, development report.

- Qualification and validation phase: obtained the master validation plan to carry out the project qualification, commissioning, installation qualification, operational qualification, performance qualification and process validation.

- Verification phase: manufacture 03 batches and these must demonstrate that the process parameters are under established control.

Figure 1 shows the synthesis of the 4 phases of the proposed model.

It can be concluded that the comparison of the technology transfer guides, added to the interviews carried out, provided subsidies to propose a harmonized model for better management and decision making. Thus, new information is included, such as the description of the implementation phases, the definition of the responsibilities of the participants in each step, control of changes and definition of responsibilities

\section{Ethics approval and consent to participate}

Ethical approval was obtained from the institutional review 
Table 1: Summary of Guides recommendations.

Guides COMPARISON BETWEEN THE GUIDES Phases

Organization and management

Production: transfer (processing, packaging and cleaning)

Quality control: analytical method transfer

WHO

Premises and equipment

Documentation

Qualification and validation

Planning

Preparation Process

PDA

Implementation and Qualifications

Licensing and Production

Project Closure

\section{Technology transfer steps}

Create team in both company - Sending company (SC) and Receiving company (RC)

Multidisciplinary team

- Training programs

Elaborate a transfer technology project

Define the level and details of technology transfer

- Information about the process and development of the product

- Transfer of all analytical methods

Analytical methods training

- Information about layout, construction and finish of buildings and services

- List of equipment, makes and models used in production

Informations about qualification and validation protocols

- Information about active pharmaceutical ingredients (API) and excipients like specifications, supplier,

analysis method qualification protocol and

report design, qualification and validation

protocol and report,

- Based on risk management principles

-- Create team in both company - SC and RC

Elaborate a transfer technology project

- Gap analysis

Define the level and details of technology transfer

- Define control strategy

Information about layout, construction and finish of buildings and services

- Transfer of documentation

Change control

Training programs

Development data in process management

Installation and qualification of equipments, preliminary batches are conducted

Manufacturing capacity assessments

- Transfer of all analytical methods

Analytical methods training

Microbial and in-process monitoring

Cleaning and process validation

Report submission to regulatory agencies

Expansion process for commercial production

Monitoring of production batches

Elaborate technology transfer report

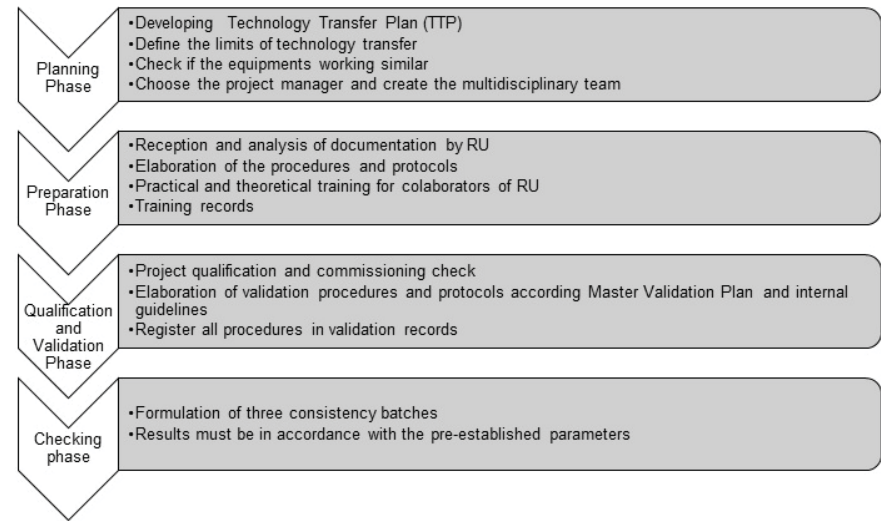

Figure 1: Planning phases for technology transfer.

Source: created by the authors.

board of INI/FIOCRUZ, final opinion number 3.353.006. Data were kept confidential and anonymous.

Funding

The project was partially funded by Biomanguinhos/ FIOCRUZ.

\section{Authors' contributions}

GRB participates in the beginning, designing, collecting data and writing the manuscript. JLM and AL guided, analyzed and revised all stages of the manuscript. JLM is the corresponding author of the manuscript.

\section{Acknowledgements}

Special thanks to Biomanguinhos/FIOCRUZ for this research, Health facilities, and for Professional Postgraduate Program in Management, Research and Development at Farmanguinhos/ FIOCRUZ co-operation to be conducted the research.

\section{References}

1. IQVIA (2018) Channel Dynamics Global Reference 2018. Link: https://bit.ly/2Xuzqmr

2. Magalhães JL (2011) Laboratórios farmacêuticos oficiais e sua relevância para saúde pública do Brasil. Reciis 5: 85-99. Link: https://bit.ly/2ywHASL

3. Mohite PB, Sangle SV, Bhusan B, Nautiyal U, Kumar S, et al. (2017) Technology transfer in Pharmaceutical Industry: A review. International Journal of Advances in Pharmaceutics 6: 1-7.

Citation: Magalhães JL, Viçosa AL, De Barros GR (2020) Technology transfer model for the formulation stage in biological products for public health Arch Community Med Public Health 6(1): 084-087. DOI: https://dx.doi.org/10.17352/2455-5479.000084 
4. WHO (2011) Annex 7 WHO guidelines on transfer of technology. WHO Technical Report 961: 285-309. Link: https://bit.ly/2Zz4C6J

5. Brekke OH, Sandlie I (2003) Therapeutic antibodies for human diseases at the dawn of the twenty-first century. Nat Rev Drug Discov 2: 52-62. Link: https://bit.ly/2AWfcKE

6. Moon S, Bermudez J, 't Hoen E (2012) Innovation and Access to Medicines for Neglected Populations: Could a Treaty Address a Broken Pharmaceutical R\&D System? PLoS Med 9: e1001218. Link: https://bit.ly/3ekCh8q

7. World Health Organization (2016) WHO | Sixty-ninth World Health Assembly Switzerland. Link: https://bit.ly/3gq1G22

8. Alam MS, Ahmad J (2013) Pharmaceutical Technology Transfer: An Overview International Journal of Pharmaceutical Sciences and Research IJPSR 4 2441-2449. Link: https://bit.ly/36sTyJO
9. Kumar V, Kumar U, Persaud A (1999) Building technological capability through importing technology: The case of Indonesian manufacturing industry. Journal of Technology Transfer 24: 81-96. Link: https://bit.ly/2TGRg4F

10. PDA (2014) Technical Report No 65 Technology Transfer. 1. Link: https://bit.ly/2A5h5Eu

11. Campos ALN (2014) Modelagem de Processos com BPMN (Brasport, Org.; 2a edição)

12. Magalhães J, Hartz Z, Temido M, Antunes A (2018) Gestão do conhecimento em tempos de big data: um olhar dos desafios para os sistemas de saúde. Anais 17. Link: https://bit.ly/3gmWigm

13. HO PL, Miyaji EN, Oliveira MLS, Dias WO, Kubrusly FS, et al. (2011) Economical value of vaccines for the developing countries--the case of Instituto Butantan, a public institution in Brazil. Link: https://bit.ly/3d2yV9D

\section{Discover a bigger Impact and Visibility of your article publication with} Peertechz Publications

\section{Highlights}

* Signatory publisher of ORCID

- Signatory Publisher of DORA (San Francisco Declaration on Research Assessment)

* Articles archived in worlds' renowned service providers such as Portico, CNKI, AGRIS, TDNet, Base (Bielefeld University Library), CrossRef, Scilit, J-Gate etc.

* Journals indexed in ICMJE, SHERPA/ROMEO, Google Scholar etc.

* OAI-PMH (Open Archives Initiative Protocol for Metadata Harvesting)

* Dedicated Editorial Board for every journal

* Accurate and rapid peer-review process

* Increased citations of published articles through promotions

* Reduced timeline for article publication

Submit your articles and experience a new surge in publication services (https://www.peertechz.com/submission).

Peertechz journals wishes everlasting success in your every endeavours.

Copyright: ( $) 2020$ Magalhães JL, et al. This is an open-access article distributed under the terms of the Creative Commons Attribution License, which permits unrestricted use, distribution, and reproduction in any medium, provided the original author and source are credited.

Citation: Magalhães JL, Viçosa AL, De Barros GR (2020) Technology transfer model for the formulation stage in biological products for public health Arch Community Med Public Health 6(1): 084-087. DOI: https://dx.doi.org/10.17352/2455-5479.000084 